\title{
Fisheries Instrument Choice under Uncertainty
}

\author{
Tom Kompas, Tuong Nhu Che, and R. Quentin Grafton
}

\begin{abstract}
This paper uses data from an actual fishery to construct a tractable, dynamic model to compare expected profit and its variance, optimal stock size, optimal harvest rate, and optimal fishing effort under different management regimes under uncertainty. The results provide a comparison of instrument choice between a total harvest control and a total effort control under uncertainty, an original method to evaluate the tradeoffs between profits and other criteria in a dynamic context, and insights regarding the relative merits of catch and effort controls in fisheries management. (JEL Q22, D81)
\end{abstract}

\section{INTRODUCTION}

A major focus of fisheries economics is designing the appropriate set of instruments to achieve desired management objectives, such as sustainability and economic efficiency. An important consideration when choosing between alternatives is the uncertainty associated with total allowable catch (TAC) controls, and the uncertainty associated with effort controls, denoted by total allowable effort (TAE). The principal causes of uncertainty are unexpected realizations in terms of the stock size such that the TAC is set at either too high or too low a level, and unexpected realizations in terms of the catch-effort relationship such that fishing effort is set at an inappropriate level.

Uncertainty in stock size is often cited as one of the main limitations of TAC controls in fisheries. This is because some knowledge of stocks is required to be able to set a TAC that, in turn, also determines any quota allocations vessels may obtain under an individual transferable quota system. If the TAC is set too high because the stock is less than expected, the risk is that managers will place excessive pressure on stocks in low abundance years, with the potential for

Land Economics • November 2008 • 84 (4): 652-666 ISSN 0023-7639; E-ISSN 1543-8325

(C) 2008 by the Board of Regents of the

University of Wisconsin System substantial reductions in the total catch in the future. If the TAC is set at too low a level because fish stocks are greater than expected, managers reduce the profitable opportunities available to fishers. A similar problem also exists in terms of effort controls except the uncertainty arises in the catch-effort relationship, usually denominated by the catch per unit of effort (CPUE). If the CPUE is higher than expected, then a fishery manager risks setting a TAE that is too large and thus places at risk the sustainability of fish stocks and also increases the per unit cost of fishing in future years. If the CPUE is less than expected, then the TAE will be set at too low a level, and this will also reduce the profitable opportunities available to fishers. In both cases (TAC or TAE controls), unexpected realizations in stock size or in the CPUE will result in errors and a failure to achieve management objectives.

In this paper, we examine the relative merits of TAC versus TAE controls, using data from an actual fishery. Our work builds on the insights of Reed (1979) in terms of optimal escapement under uncertainty, Clark and Kirkwood (1986) on optimal harvest with fluctuating stocks, and the works of Hannesson and Steinshamn (1991), Quiggin (1992), and Danielsson (2002a, 2002b) who compare effort and catch controls in a stochastic environment. Hannesson and Steinshamn (1991) in a single-period model compared expected profits with a TAC and with a TAE and, under reasonable assumptions about the

The authors are, respectively, associate professor, Crawford School of Economics and Government, the Australian National University; senior economist, Australian Bureau of Agricultural and Resource Economics; and professor, Crawford School of Economics and Government, the Australian National University. Thanks to two anonymous referees for very helpful comments on this paper. 
curvature of the revenue and cost functions, found that a TAC gives both higher expected revenues and also harvesting costs relative to a TAE when the only source of uncertainty is stock size. Quiggin (2002) used the same oneperiod model and showed that if stocks are independently and identically distributed there is a constant TAE control that yields a higher profit than a fixed TAC. Danielsson (2002a, 2002b) added another type of uncertainty in terms of the CPUE, in addition to uncertainty with respect to stock size, so as to make a fairer comparison of the two instruments. He found that, all else equal, the greater the variability in the CPUE relative to the growth in the stock the greater is the comparative advantage of a TAC relative to a TAE.

We use data from the Northern Prawn fishery (NPF) of Australia to compare the relative merits of TAC and TAE controls in the presence of uncertainty using an explicit dynamic model. We do not consider the incentives issues of input versus output controls, nor do we examine differences in costs of management because these have been examined in detail elsewhere (Campbell and Lindner 1990; Grafton et al. 2006; Townsend 1990). As far as we are aware, our analysis is the first to make dynamic comparisons between TAC and TAE controls under uncertainty using actual fisheries data. We also extend the results of Danielsson into a fully dynamic model that examines the effects on the variance of expected profits, fish stocks, the catch rate and fishing effort. Further, we provide a practical method to compare TAC and TAE controls under uncertainty.

Section 2 provides a brief description of the NPF. Section 3 sets out the theoretical framework, including the biological model, the relationship between catch and catch per unit of effort, the economic model and the optimizing framework to compare TAC and TAE controls. We use a genetic algorithm in Section 4 to solve the model for a set of parameters and compare differences between expected profit, stock size, catch rate and fishing effort under TAC and TAE controls. Section 5 provides additional scenarios to compare the two instruments while Section 6 concludes.

\section{AUSTRALIAN NORTHERN PRAWN FISHERY}

The NPF occupies a very large area of the ocean off Australia's northern coast. The fishery extends from the low water mark to the outer edge of the Australian fishing zone (AFZ) along approximately 6,000 kilometres of coastline between Cape York in Queensland and Cape Londonderry in Western Australia (AFMA 2002).

The Northern Prawn Fishery (NPF) is Australia's most valuable Commonwealth fishery. The fishery was first established commercially in the late 1960s. There are more than fifty species of prawn that inhabit Australia's tropical northern coastline, but only about nine species of prawns are caught. Three species (the white banana prawn Fenneropenaeus merguiensis the brown tiger prawn Penaeus esculentus, and the grooved tiger prawn $P$. semisulcatus) account for almost $80 \%$ of the total annual landed catch (in terms of weight) from the fishery (Galeano et al. 2006). Banana prawns are caught at different times of the year, and the two main species of tiger prawns are caught in the winter months. When fishing for tiger prawns, vessels utilize twin-rigged otter trawl nets that sweep the bottom of the ocean behind the fishing vessel. The netting at the mouth of the net is hung from a headrope at the top and a footrope stretched between otter boards. Operators can regulate the width of their net according to the angle and lateral force of the net otter boards (AFMA 1999).

Annual catches during 2002-2005 ranged from 5,100 to 6,300 metric tons per year (Galeano et al. 2006). The annual gross value of prawn production in the NPF in 2002-2005 was A \$65 million to A \$80 million, of which the share of tiger and banana prawn is roughly $45 \%$ and $47 \%$ respectively (Galeano et al. 2006). Nearly $90 \%$ of all prawn output is exported to Japan and Asia.

There are currently 124 fishing concessions in the fishery, however, only 95 
trawlers fished in 2004. At the start of 2004 the fishing fleet was comprised of 95 twinrigged trawlers of up to 29.2 meters in length. These trawlers are capable of sorting, grading, packing, and freezing catches at sea. The most common NPF vessel length is between 22.00 and 23.00 meters. In 2004, the most common headrope length per vessel was between 22 and 23.9 fathoms (40.2 and 43.7 meters), with around $48 \%$ of the fleet using this length. The average headrope length was 22.3 fathoms (40.8 meters) (AFMA 2006a). A mix of independent single boat owners, small fleet owners, and corporate operators with between 9 and 12 vessels each owns the fleet (AFMA 2006b). In 2004-2005 average annual fishing days were approximately 10,000 and 5,000 days for tiger prawn and banana prawn respectively (AFMA 2006a). On average, during the period 2003-2005 fishing effort per vessel ranged from 150 to 200 days a year.

The fishery is managed under the Northern Prawn Fishery Management Plan 1995. To date, a series of input controls have been used to regulate the fishery. These controls include limited entry and gear restrictions (through the issuing of Statutory Fishing Rights or SFRs), a system of spatial and temporal closures, and by-catch restrictions (AFMA 2002). The SFRs control fishing capacity by placing limits on the numbers of boats and the amount of gear permitted in the fishery. In its relatively short history, the fishery has experienced a significant variation in catch. Low prawn prices reduced profitability in the $1980 \mathrm{~s}$ and led to restructuring of the fleet in the late 1980s and early 1990s. The fleet structure has also changed gradually since the 1970s with a transition from wooden trawlers with brine tanks and iceboxes toward larger, purposebuilt, steel freezer trawlers with high catch and carrying capacities.

\section{BIOECONOMIC MODELING OF THE FISHERY}

To compare TAC and TAE controls under uncertainty, we need a biological model of the stock recruitment relationship and a specification regarding the relationship between fishing effort and the total catch.

\section{Stock-Recruitment Relationship}

The spawning stock-recruitment relationship is based on Ricker's equation (Ricker 1954), that is,

$R_{t}=\alpha_{1} \hat{S}_{t-1} e^{\beta_{1} \hat{S}_{t-1}}+\xi_{1}$,

where $R_{t}$ is the total number of recruits produced in year $t$ and $\hat{S}_{t-1}$ is the spawning stock of the previous year (estimated as the number of prawns). The parameters $\alpha_{1}$ and $\beta_{1}$ determine the relationship between recruitment and the number of spawners in the previous year while the term $\xi_{1}$ represents uncertainty, or the stochastic behavior of the spawning stock-recruitment relationship.

The underlying relationships within the stock-recruitment relationship must also be modeled. First, the spawning stock is taken as a proportion $(\gamma)$ of the total female stock, assuming that female prawns constitute half of the total stock of prawns and the sex ratio (males to females) is $1: 1$, that is,

$\hat{S}_{t-1}=\left(\gamma S_{t-1}\right) / 2$.

Following Penn, Caputi, and Hall (1995) and Wang and Die (1996), the spawning stock $\hat{S}_{t}$ is assumed to be the result of annual recruitment $R_{t}$ and also fishing effort, defined as

$\hat{S}_{t}=\alpha_{2} R_{t} e^{-\beta_{2}\left(F_{t}+m\right)}$,

where $F_{t}$ is fishing mortality at year $t$ and $m$ is the annual natural mortality rate; $\alpha_{2}$ and $\beta_{2}$ are the parameters. Using existing studies from the NPF, Wang and Die (1996) define fishing mortality in year $t$ as follows:

$F_{t}=q \times E_{t}^{\eta}=q \times B_{t} \times N_{t}$,

where $q$ is the "catchability coefficient" and $E_{t}$ is fishing effort at year $t ; B_{t}$ is the number of standard boats; and $N_{t}$ is nominal fishing 
days. The share coefficient on effort $(\eta)$ is estimated to equal one in Wang and Die (1996).

Fishing effort is determined as total "standard" boat days in the fishery, which is a multiple of total "standard" boats $\left(B_{t}\right)$ and nominal fishing days in the season $\left(N_{t}\right)$. In the NPF, one unit of fishing effort is defined as the daily effort of a "standard" boat that equates boat day units between large and small vessels. In practical terms, this capacity can be measured by boat engine power and a measure of hull size. For example, in the NPF boat size is measured in terms of A-units, as a simple linear combination of a kilowatt of engine power and a cubic meter of hull. Thus if we define a standard boat size as $\dot{\bar{A}}$ units then the total standard boat numbers at year $t$ is given by

$B_{t}=\sum_{i=1}^{M} \frac{A_{i t}}{\bar{A}}$,

where $M$ is the number of boats in the fishery and $A_{i t}$ the size of boat $i$ in units in year $t$. If there is technological change then [4] needs to be adjusted such that

$F_{t}=q \times E_{t}=q \times T E C_{t} \times B_{t} \times N_{t}$,

where $T E C_{t}$ measures the percentage change in technology (measured by "fishing power" in the NPF) at year $t$.

\section{Catch Per Unit of Effort (CPUE)}

To assess the effect of uncertainty on CPUE, we must also specify a relationship between total catch and the biology of the fishery. Based on previous work on the NPF, Wang and Die (1996) use the following specification for the catch rate,

$h_{t}=\alpha_{3} R_{t} \frac{F_{t}}{F_{t}+m}\left(1-e^{-\beta_{3}\left(F_{t}+m\right)}\right)$,

where $h_{t}$ is the annual catch in metric tons that increases asymptotically to a maximum of $\alpha_{3} R_{t}$ as fishing effort tends to infinity (Wang and Die 1996).
Using [7], CPUE at a given point in time is

$$
\begin{aligned}
\text { CPUE }_{t}= & \frac{h_{t}}{E_{t}} \\
= & \left(\alpha_{3} R_{t} \frac{F_{t}}{F_{t}+m}\left(1-e^{-\beta_{3}\left(F_{t}+m\right)}\right)\right) \\
& \div\left(E_{t}\right)+\xi_{2},
\end{aligned}
$$

where $\xi_{2}$ represents stochastic behavior associated with CPUE.

From [7], under input controls catch is obtained as a function of effort, or

$h_{t}=\alpha_{3} R_{t} \frac{q E_{t}}{q E_{t}+m}\left(1-e^{-\beta_{3}\left(q E_{t}+m\right)}\right)+\xi_{2}, \quad[9 \mathrm{a}]$

and, under output controls effort is obtained as a function of catch, that is,

$$
E_{t}=\frac{1}{q}\left[\frac{1}{\beta_{3}} \ln \left(\frac{1}{1-\frac{h_{t}}{\alpha_{3} R_{t}}}\right)-m\right]+\xi_{2} .
$$

\section{Economic Model}

In order to make operational the bioeconomic model, further specifications are required in terms of total revenue and total costs. Annual total revenue of the fishery $\left(T R_{t}\right)$ is defined as the multiple of annual fish catch and the annual (average) price of fish,

$$
T R_{t}=p_{h} h_{t}
$$

where $p_{h}$ is the price of fish drawn from an inverse demand curve. Following Danielsson (2002a) and Campbell, Hand, and Smith (1993) this price is determined using the specification given in [11] with data from the period 1990-2003 (ABARE 1990-2003),

$p_{h}=p_{0}\left(H_{0} / h_{t}\right)^{1 / \varepsilon}$,

where $\varepsilon$ is the elasticity of demand for catch and $p_{0}$ is the unit price of the catch when the volume of the catch is $H_{0}$.

Annual total cost of employing the fleet is assumed to be the sum of labor, material, repair and depreciation, and other costs. Labor costs are represented as a share of 
total revenue because of the share system for the remuneration crew that also accounts for material costs such as packaging and gear maintenance expenditures. Repair and depreciation, and also other costs (of which fuel is a major component), are assumed to depend on fishing effort that is defined as total "standard" boat-days with the number of "standard" boats $\left(B_{t}\right)$ computed as per equation [5]. Thus total harvesting costs are expressed as

$$
\begin{aligned}
T C_{t}= & c_{F}+c_{L} h_{t} p_{h}+c_{M} h_{t} p_{h} \\
& +c_{K} E_{t}+c_{O} E_{t},
\end{aligned}
$$

where $c_{L}$ and $c_{M}$ are the share cost of labor and materials per each Australian dollar of output, $c_{K}$ and $c_{O}$ are, respectively, the average repair and depreciation costs and other costs per unit of effort, and $c_{F}$ is a fixed cost component. The average repair and depreciation cost of a unit of effort $\left(c_{K}\right)$ is estimated by dividing total cost for these items by total fishing effort. Average other costs $\left(c_{O}\right)$ per unit of effort are estimated by dividing total other costs by total fishing effort.

Using [11] and [12], the annual fishery profit is given by [13],

$$
\begin{gathered}
\Pi_{t}=p_{h} h_{t}-\left(c_{F}+c_{L} h_{t} p_{h}+c_{M} h_{t} p_{h}\right. \\
\left.+c_{K} E_{t}+c_{O} E_{t}\right) .
\end{gathered}
$$

\section{Optimization Model}

The stated aim of the Australian government is to maximize economic efficiency in its fisheries subject to a long-term sustainability constraint. Consequently, we specify that the management objective is to maximize expected discounted profits over time. The control variable in the case of TAE control is fishing effort $\left(E_{t}\right)$, defined as the number of nominal days fished, while with a TAC the control is exercised via the total catch $\left(h_{t}\right)$. Thus with a TAE control, assuming fishing effort is observable and also enforceable, total expected discounted profits over period $T$ are given by

$$
\begin{aligned}
\max _{E_{t}} \sum_{i=1}^{T} \hat{\Pi}_{t}= & \sum_{i=1}^{T} \frac{1}{(1+\delta)^{i}} \sum_{i=1}^{T} p_{h} h_{t}\left(E_{t}\right) \\
& -\left(c_{F}+c_{L} h_{t}\left(E_{t}\right) p_{h}\right. \\
& +c_{M} h_{t}\left(E_{t}\right) p_{h} \\
& \left.+c_{K} E_{t}+c_{O} E_{t}\right),
\end{aligned}
$$

where $\delta$ is the discount rate and $\hat{\Pi}_{t}$ is the net present value of profit at year $t$, subject to equations [1], [3], and substituting from [9a], where appropriate, to obtain a single control variable in effort.

The problem for the regulator that uses exclusively a TAC control is to maximize expected profits, or

$$
\begin{aligned}
\max _{h_{t}} \sum_{i=1}^{T} \hat{\Pi}_{t}= & \sum_{i=1}^{T}\left(\frac{1}{(1+\delta)^{t}}\right) \\
& \times\left(p_{h} h_{t}-\left(c_{F}+c_{L} h_{t} p_{h}+c_{M} h_{t} p_{h}\right.\right. \\
& \left.\left.+c_{K} E_{t}+c_{O} E_{t}\right)\right),
\end{aligned}
$$

subject to equations [1], [3], and substituting [9b], where appropriate, to obtain a single control variable in catch. Solving equations [14] or [15] also requires that spawning stock at the period $0\left(\hat{S}_{0}\right)$ be known and an appropriate transversality condition that we specify as follows, $\Pi_{T}=0$.

\section{Model Parameters}

To make the comparisons between TAC and TAE controls under uncertainty we need to specify parameter values for [14] and [15]. Many of these values are in terms of the stock-recruitment model given in [1] and fishing mortality in [6]. The parameters for the two main types of prawns (brown tiger and grooved tiger prawns) caught in the fishery are provided in Table 1 . Further details on the sources and calculations used to derive the parameters are provided in Kompas and Che (2003).

In addition to using parameter values from other studies, the stock-recruitment equation, given by equation [1] and the CPUE, given by equation [8], were estimated using an annual time-series database over the period 1971-2000. Initial values are drawn from measures in Wang and Die 
TABLE 1

Parameter Values Used in the Optimization Models

\begin{tabular}{|c|c|c|c|c|}
\hline \multirow[b]{2}{*}{$\underline{\text { Parameters }}$} & \multirow[b]{2}{*}{ Source } & \multirow[b]{2}{*}{ Units } & \multicolumn{2}{|c|}{ Parameter Values } \\
\hline & & & $\begin{array}{c}\text { Brown } \\
\text { Tiger } \\
\text { Prawn }\end{array}$ & $\begin{array}{c}\text { Grooved } \\
\text { Tiger } \\
\text { Prawn } \\
\end{array}$ \\
\hline \multicolumn{5}{|l|}{ Biological Model } \\
\hline$\hat{S}_{0}$ & CSIRO (2002a) & Million prawns & 15 & 18 \\
\hline$R_{1}$ & & Million prawns & 187 & 309 \\
\hline$\alpha_{1}$ & Wang and Die (1996) & & 14.41 & 45.96 \\
\hline$\beta_{1}$ & Wang and Die (1996) & & 0.0096 & 0.0548 \\
\hline$\alpha_{2}$ & Wang and Die (1996) & & 0.111 & 0.047 \\
\hline$\beta_{2}$ & Wang and Die (1996) & & 0.354 & 0.302 \\
\hline$m$ & $\begin{array}{l}\text { Wang (1999), Wang and } \\
\text { Die (1996) }\end{array}$ & Annual rate & 0.045 & 0.045 \\
\hline$\gamma$ & Crocos (1987a, 1987b) & Annual rate & 0.3 & 0.2 \\
\hline \multicolumn{5}{|l|}{ Fishing Model } \\
\hline$\alpha_{3}$ & Wang and Die (1996) & & 14.08 & 15.18 \\
\hline \multirow[t]{2}{*}{$\beta_{3}$} & Wang and Die (1996) & & 0.494 & 0.544 \\
\hline & & & \multicolumn{2}{|c|}{$\begin{array}{c}\text { Brown Tiger and } \\
\text { Grooved Tiger Prawns }\end{array}$} \\
\hline Number of vessels & AFMA (2002) & Number & 120 & \\
\hline Standard A-unit vessel & CSIRO (2002b) & A-unit & 400 & \\
\hline Catchability rate of one unit fishing effort & Wang (1999) & CPUE(kg/day) & & $3 \times 10^{-5}$ \\
\hline \multicolumn{5}{|l|}{ Economic Model } \\
\hline The initial price $\left(P_{0}\right)$ & ABARE (2003) & $\$ / \mathrm{kg}$ & \multicolumn{2}{|l|}{30} \\
\hline The initial catch $\left(H_{0}\right)$ & ABARE (2003) & Ton & \multicolumn{2}{|l|}{1,800} \\
\hline Price elasticity of demand & Authors' calculations & & \multicolumn{2}{|l|}{15} \\
\hline Share of labor cost per $\$ 1$ output & ABARE (1994-2001) & & \multicolumn{2}{|c|}{0.26} \\
\hline Share of materials costs per $\$ 1$ output & ABARE (1994-2001) & & \multicolumn{2}{|c|}{0.25} \\
\hline $\begin{array}{l}\text { Average repair and depreciation per a unit of } \\
\text { fishing effort }\left(c_{K}\right)\end{array}$ & ABARE (1994-2001) & $\begin{array}{l}\text { \$ per "standard" } \\
\text { boat-day }\end{array}$ & \multicolumn{2}{|l|}{884} \\
\hline $\begin{array}{l}\text { Average other costs per unit of fishing effort } \\
\left(c_{O}\right)\end{array}$ & ABARE (1994-2001) & $\begin{array}{l}\text { \$ per "standard" } \\
\text { boat-day }\end{array}$ & \multicolumn{2}{|l|}{1,180} \\
\hline
\end{tabular}

(1996). Both equations were estimated using Non-Linear Least Squares (NLS) estimation techniques in Microfit 5.1. The estimating equation for the stock recruitment relationship is

$R_{t}=\alpha_{1} \hat{S}_{t-1} e^{\beta_{1} \hat{S}_{t-1}}+u_{t}\left(\bar{u}, \xi_{3}\right)$,

where $u_{t}$ is the residual of the regression with mean value $\bar{u}$ and standard deviation $\xi_{3}$. The estimating equation for the CPUE relationship is as follows:

$$
\begin{gathered}
C P U E_{t}=\frac{h_{t}}{E_{t}}=( \\
\left.\alpha_{3} R_{t}\left(1-e^{-\beta_{3}\left(F_{t}+m\right)}\right)\right) \\
\div\left(E_{t}\right)+u_{t}\left(\bar{u}, \xi_{4}\right),
\end{gathered}
$$

where $u_{t}$ is the residual of the regression with the mean value $\bar{u}$ and standard deviation $\xi_{4}$. The estimated results for the two equations are provided in Table 2 where the standard deviations have been converted to percentage deviations.

The estimated parameters and standard deviations of the regression equations for [16] and [17] are provided in Table 2. The results both support the previous biological studies and also the application of the CPUE equation given by [8]. Table 2 also shows that the variance in the stockrecruitment relationship is smaller in all cases than that for CPUE. 
TABLE 2

Non-Linear Estimated Results for the Ricker EQuATION [16] AND THE CPUE EQUATION [17] Using 1971-2000 DATA

\begin{tabular}{lcc}
\hline \hline & $\begin{array}{c}\text { Brown } \\
\text { Tiger }\end{array}$ & $\begin{array}{c}\text { Grooved } \\
\text { Tiger }\end{array}$ \\
\hline Ricker Equation [16] & & \\
Coefficient $\alpha_{1}$ & & \\
$\quad$ Estimate & 14.41 & 45.96 \\
$\quad t$-ratio & 6.09 & 9.26 \\
$p$-value & 0.000 & 0.000 \\
Coefficient $\beta_{1}$ & & \\
$\quad$ Estimate & 0.0096 & 0.0548 \\
$t$-ratio & 3.16 & 4.16 \\
$p$-value & 0.004 & 0.000 \\
Standard deviation of the residuals of & $21.45 \%$ & $15.92 \%$ \\
$\quad$ the regression $\left(\xi_{3}\right)$ & & \\
$C P U E$ Equation $[17]$ & & \\
Coefficient $\alpha_{3}$ & & \\
$\quad$ Estimate & & \\
$t$-ratio & 14.03 & 15.18 \\
$p$-value & 2.91 & 1.94 \\
Coefficient $\beta_{3}$ & 0.007 & 0.063 \\
$\quad$ Estimate & & \\
$t$-ratio & & \\
$p$-value & 0.494 & 0.544 \\
Standard deviation of the residuals of & $25.53 \%$ & $23.155 \%$ \\
$\quad$ the regression $\left(\xi_{4}\right)$ & & \\
\hline$\quad$ & 3.04 & 1.5 \\
\hline & &
\end{tabular}

\section{OPTIMAL SOLUTIONS FOR THE BIOECONOMIC MODELS}

Given the nonlinear relationships in the bioeconomic models and the stochastic nature of the problem - a genetic algorithm (Goldberg 1989) imported into MAPLE 10.0 that is available upon request - was used to solve for the optimal solution to the TAE control problem in [14] and the TAC control problem in [15]. Using the estimated standard deviations in Table 2, the optimal solutions for a non-stochastic $\left(\xi_{3}=\xi_{4}=0\right)$ version of the model, and also a stochastic version, are presented in Table 3. Although the model values (profits, stock size, etc.) change with discounting, and important issues are associated with how the future costs and benefits are discounted (Sumaila and Walters 2005), the qualitative difference between TAE and TAC controls is invariant to the rate of discount. For completeness, Table 3 presents the model results without discounting, while Table 4 provides results at a discount rate of $3 \%$, which is the rate used by the Australian government used for public investments.

In Tables 3 and 4 the time horizon is 50 years, long enough to guarantee that optimal results are sufficiently close to their steady state values before diverting to meet a terminal condition in year 50 . The terminal condition is such that the value of profits at year 50 goes to zero. As a result near the terminal state or year 50, effort and catch increase and stock size falls dramatically as the terminal condition of zero profits is met.

Table 3 shows that in the absence of uncertainty and with perfect information and enforcement, the TAC and TAE controls yield identical results. Figure 1 graphs effort, catch, and stock for both output and input controls. Given that the current stock levels in the NPF are lower than the optimal level, initial effort is low until stock recovers to its "near" steady state value. Near the terminal state, or year 50 , effort and catch increase and stock size falls dramatically as the terminal condition of zero profits is met. Slight random variations in each path are due to the random search process for optimal results imbedded in the genetic algorithm.

Using the estimated measures of uncertainty in the fishery we show there is a difference between the two instruments. The stochastic model assumes variance in stock and CPUE, calibrated to the NPF, so that the variance in the stock-recruitment relationship is less than the variance in CPUE. An important observation is that uncertainty generates lower optimal profit levels compared to the base case, as expected, and regardless of the management device used. However the key comparison is between TAE and TAC controls. Given that the estimated standard deviation in the stock recruitment relationship is lower than in the CPUE relationship, a TAC control out-performs a TAE control in terms of expected profits by about A $\$ 13$ million for the fishery as a whole, or approximately A $\$ 2,200$ per boat per year, in present value 
TABLE 3

Optimal Solutions of the Base-Case and Stochastic Models without Discounting

\begin{tabular}{|c|c|c|c|}
\hline & Unit & TAC Control & TAE Control \\
\hline \multicolumn{4}{|l|}{ 1. Base Model } \\
\hline Total expected profit (mean value) & AS & $732,000,000$ & $732,000,000$ \\
\hline \multicolumn{4}{|l|}{ Mean Values at Steady State } \\
\hline $\begin{array}{l}\text { Total stock size } \\
\text { Stock size of Brown Tiger } \\
\text { Stock size of Grooved Tiger } \\
\text { Annual catch } \\
\text { Number of boats in a year } \\
\text { Fishing days per boat per year } \\
\text { Total boat days per year }\end{array}$ & $\begin{array}{l}\text { Millions of prawns } \\
\text { Millions of prawns } \\
\text { Metric ton } \\
\text { Boat } \\
\text { Day } \\
\text { Boat-day }\end{array}$ & $\begin{array}{r}308 \\
205 \\
103 \\
2,240 \\
120 \\
70 \\
8,400\end{array}$ & $\begin{array}{r}308 \\
205 \\
103 \\
2,240 \\
120 \\
70 \\
8,400\end{array}$ \\
\hline \multicolumn{4}{|l|}{ Average Values per Year } \\
\hline $\begin{array}{l}\text { Total stock size } \\
\text { Stock size of Brown Tiger } \\
\text { Stock size of Grooved Tiger } \\
\text { Annual catch } \\
\text { Number of boats } \\
\text { Fishing days per boat per year } \\
\text { Total boat days }\end{array}$ & $\begin{array}{l}\text { Millions of prawns } \\
\text { Millions of prawns } \\
\text { Metric ton } \\
\text { Boat } \\
\text { Day } \\
\text { Boat-day }\end{array}$ & $\begin{array}{r}304 \\
198 \\
106 \\
2,140 \\
120 \\
67 \\
8,040\end{array}$ & $\begin{array}{r}304 \\
198 \\
106 \\
2,140 \\
120 \\
67 \\
8,040\end{array}$ \\
\hline \multicolumn{4}{|l|}{ 2. Stochastic Recruitment and CPUE Model } \\
\hline $\begin{array}{l}\text { Total expected profit (mean value) } \\
\text { Standard of deviation }\end{array}$ & $\begin{array}{l}\text { A } \$ \\
\text { Million }\end{array}$ & $\begin{array}{r}658,000,000 \\
40,000,000\end{array}$ & $\begin{array}{l}645,000,000 \\
152,000,000\end{array}$ \\
\hline \multicolumn{4}{|l|}{ Mean Values at Steady State } \\
\hline $\begin{array}{l}\text { Total stock size } \\
\text { Stock size of Brown Tiger } \\
\text { Stock size of Grooved Tiger } \\
\text { Annual catch } \\
\text { Number of boats in a year } \\
\text { Fishing days per boat per year } \\
\text { Total boat days per year at the steady state }\end{array}$ & $\begin{array}{l}\text { Millions of prawns } \\
\text { Millions of prawns } \\
\text { Metric ton } \\
\text { Boat-day } \\
\text { Day } \\
\text { Boat-day }\end{array}$ & $\begin{array}{r}330 \\
227 \\
106 \\
2,060 \\
120 \\
61 \\
7,320\end{array}$ & $\begin{array}{r}324 \\
219 \\
105 \\
2,100 \\
120 \\
63 \\
7,560\end{array}$ \\
\hline \multicolumn{4}{|l|}{ Average Values per Year } \\
\hline $\begin{array}{l}\text { Total stock size } \\
\text { Stock size of Brown Tiger } \\
\text { Stock size of Grooved Tiger } \\
\text { Annual catch } \\
\text { Number of boats } \\
\text { Fishing days per boat per year } \\
\text { Total boat days }\end{array}$ & $\begin{array}{l}\text { Millions of prawns } \\
\text { Millions of prawns } \\
\text { Metric ton } \\
\text { Boat-day } \\
\text { Day } \\
\text { Boat-day }\end{array}$ & $\begin{array}{r}321 \\
213 \\
108 \\
1,950 \\
120 \\
58 \\
6,960\end{array}$ & $\begin{array}{r}317 \\
211 \\
106 \\
2,070 \\
120 \\
62 \\
7,440\end{array}$ \\
\hline
\end{tabular}

terms. This is because a TAE tends to overshoot and undershoot more than a TAC, when the desired level of each instrument is set before knowing the actual realization of the CPUE, or the level of the stock, thus reducing profit-making opportunities available to fishers. In addition, the standard deviation in mean expected profit is less than a third with a TAC versus a TAE control while the stock size with a TAC is also higher than with a TAE, and also has a lower standard deviation.
The optimal solutions for the case with a social-economic discount rate of $3 \%$ are reported in Table 4 . Both cases indicate a greater catch earlier in the planning horizon and consequently smaller "near" steadystate stocks than in cases without discounting. With discounting, future catch is valued less today generating a preference for increases in catch in transition than in the steady state, as has been shown in the literature (Berman and Sumaila 2006). Catch and fishing effort per boat per year 
TABLE 4

Optimal Solutions of the Base-Case and Stochastic Models with a Discount Rate $(\delta=3 \%)$

\begin{tabular}{|c|c|c|c|}
\hline & Unit & TAC Control & TAE Control \\
\hline \multicolumn{4}{|l|}{ 1. Base Model } \\
\hline Total expected profit (mean value) & AS & $365,000,000$ & $365,000,000$ \\
\hline \multicolumn{4}{|l|}{ Mean Values at Steady State } \\
\hline $\begin{array}{l}\text { Total stock size } \\
\text { Stock size of Brown Tiger } \\
\text { Stock size of Grooved Tiger } \\
\text { Annual catch } \\
\text { Number of boats in a year } \\
\text { Fishing days per boat per year } \\
\text { Total boat days per year }\end{array}$ & $\begin{array}{l}\text { Millions of prawns } \\
\text { Millions of prawns } \\
\text { Metric ton } \\
\text { Boat } \\
\text { Day } \\
\text { Boat-day }\end{array}$ & $\begin{array}{r}302 \\
203 \\
99 \\
2,350 \\
120 \\
77 \\
9,240\end{array}$ & $\begin{array}{r}302 \\
203 \\
99 \\
2,350 \\
120 \\
77 \\
9,240\end{array}$ \\
\hline \multicolumn{4}{|l|}{ Average Values per Year } \\
\hline $\begin{array}{l}\text { Total stock size } \\
\text { Stock size of Brown Tiger } \\
\text { Stock size of Grooved Tiger } \\
\text { Annual catch } \\
\text { Number of boats } \\
\text { Fishing days } \\
\text { Total boat days }\end{array}$ & $\begin{array}{l}\text { Millions of prawns } \\
\text { Millions of prawns } \\
\text { Metric ton } \\
\text { Boat } \\
\text { Day } \\
\text { Boat-day }\end{array}$ & $\begin{array}{r}298 \\
196 \\
102 \\
2,250 \\
120 \\
73 \\
8,760\end{array}$ & $\begin{array}{r}298 \\
196 \\
102 \\
2,250 \\
120 \\
73 \\
8,760\end{array}$ \\
\hline \multicolumn{4}{|l|}{ 2. Stochastic Recruitment and CPUE Model } \\
\hline $\begin{array}{l}\text { Total expected profit (mean value) } \\
\text { Standard deviation }\end{array}$ & $\begin{array}{l}\text { A\$ } \\
\text { Million }\end{array}$ & $\begin{array}{r}328,000,000 \\
21,000,000\end{array}$ & $\begin{array}{r}326,000,000 \\
79,000,000\end{array}$ \\
\hline \multicolumn{4}{|l|}{ Mean Values at Steady State } \\
\hline $\begin{array}{l}\text { Average stock size } \\
\text { Stock size of Brown Tiger } \\
\text { Stock size of Grooved Tiger } \\
\text { Annual catch } \\
\text { Number of boats in a year } \\
\text { Fishing days per boat per year } \\
\text { Total boat days per year at the steady state }\end{array}$ & $\begin{array}{l}\text { Millions of prawns } \\
\text { Millions of prawns } \\
\text { Metric ton } \\
\text { Boat-day } \\
\text { Day } \\
\text { Boat-day }\end{array}$ & $\begin{array}{r}329 \\
223 \\
106 \\
2,080 \\
120 \\
63 \\
7,560\end{array}$ & $\begin{array}{r}322 \\
217 \\
105 \\
2,120 \\
120 \\
64 \\
7,680\end{array}$ \\
\hline \multicolumn{4}{|l|}{ Average Values per Year } \\
\hline $\begin{array}{l}\text { Total stock size } \\
\text { Stock size of Brown Tiger } \\
\text { Stock size of Grooved Tiger } \\
\text { Annual catch } \\
\text { Number of boats } \\
\text { Fishing days } \\
\text { Total boat days }\end{array}$ & $\begin{array}{l}\text { Millions of prawns } \\
\text { Millions of prawns } \\
\text { Metric ton } \\
\text { Boat-day } \\
\text { Day } \\
\text { Boat-day }\end{array}$ & $\begin{array}{r}320 \\
216 \\
104 \\
2,020 \\
120 \\
61 \\
7,320\end{array}$ & $\begin{array}{r}315 \\
208 \\
105 \\
2,060 \\
120 \\
63 \\
7,560 \\
\end{array}$ \\
\hline
\end{tabular}

in the base case are thus higher for the discounted case being some 2,350 metric tons and 77 days while they are 2,240 metric tons and 70 days without discounting. To maintain catch at higher levels the stock must be smaller, indicating that discounting is less "conservationist" than the case of no discounting. Discounting, however, does not change the qualitative difference between TAC and TAE controls. For instance, as with the case of a zero discount rate, a TAC is preferred to TAE control because it generates a higher mean expected profit, a much lower standard deviation of mean expected profits, a higher stock size and lower fishing effort in terms of total boat days.

\section{UNCERTAINTY SCENARIOS AND INSTRUMENT CHOICE}

To further analyze the effects of the estimated uncertainties on instrument choice we generate three counterfactual 


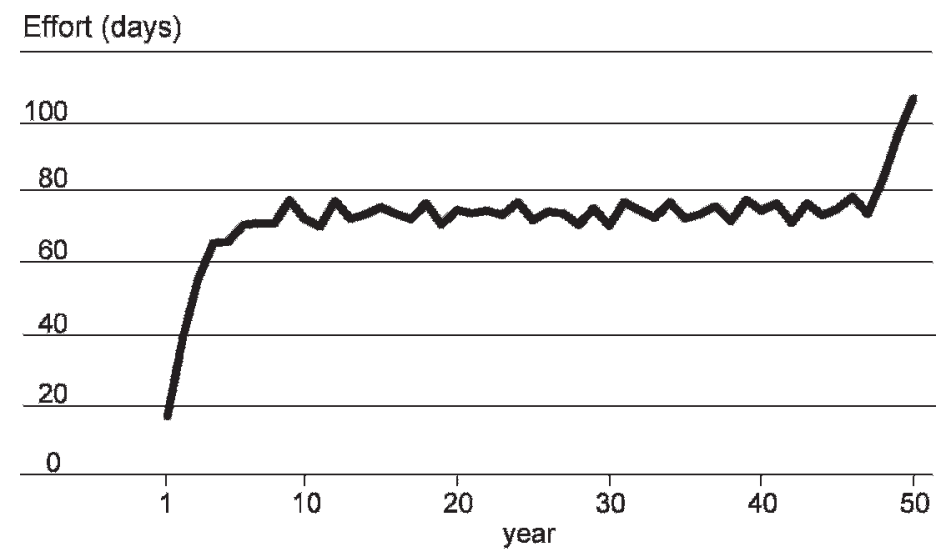

Harvest (tons)

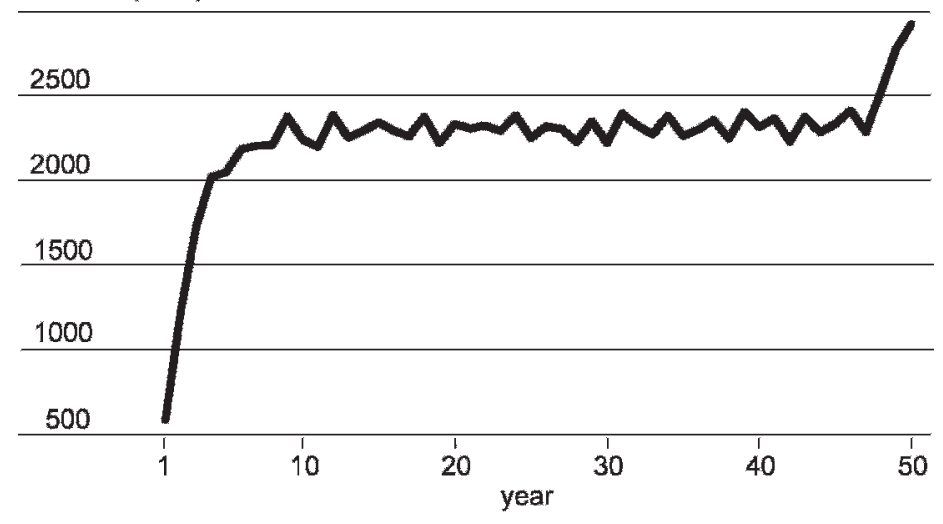

Stock (millions)
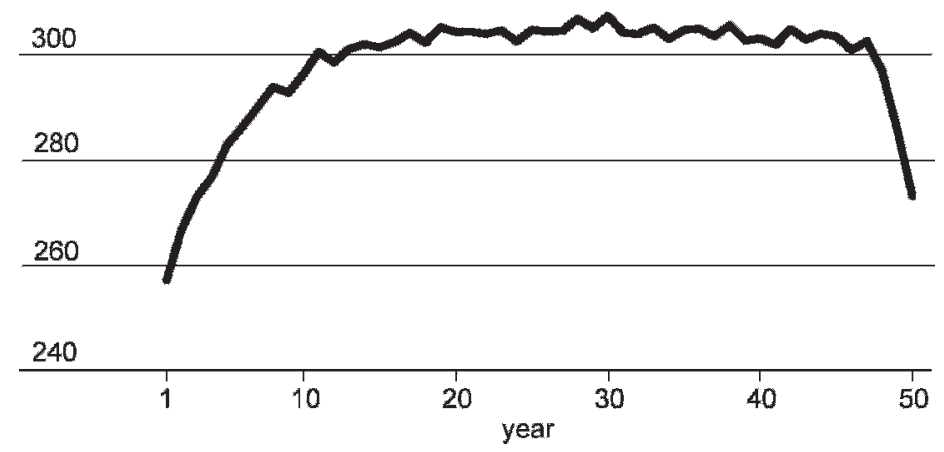

FIGURE 1

Transitional Paths of Stock Size, Catch, and Effort in the Base Model 
TABLE 5

Optimal Solutions under Three Uncertainty Scenarios

\begin{tabular}{|c|c|c|c|}
\hline & Unit & TAC Control & TAE Control \\
\hline \multicolumn{4}{|l|}{ Case One } \\
\hline $\begin{array}{l}\text { Total expected profit (mean value) } \\
\text { Standard deviation of expected profits }\end{array}$ & AS & $\begin{array}{r}661,000,000 \\
31,000,000\end{array}$ & $\begin{array}{r}670,000,000 \\
46,000,000\end{array}$ \\
\hline \multicolumn{4}{|l|}{ Mean Values at Steady State } \\
\hline $\begin{array}{l}\text { Total stock size } \\
\text { Annual catch } \\
\text { Number of boats in a year } \\
\text { Fishing days in a year } \\
\text { Total boat days per year }\end{array}$ & $\begin{array}{l}\text { Millions of prawns } \\
\text { Metric ton } \\
\text { Boat } \\
\text { Day } \\
\text { Boat-day }\end{array}$ & $\begin{array}{r}327 \\
2,070 \\
120 \\
62 \\
7,440\end{array}$ & $\begin{array}{r}316 \\
2,160 \\
120 \\
67 \\
8,040\end{array}$ \\
\hline \multicolumn{4}{|l|}{ Average Values per Year } \\
\hline $\begin{array}{l}\text { Total stock size } \\
\text { Annual catch } \\
\text { Number of boats } \\
\text { Fishing days } \\
\text { Total boat days }\end{array}$ & $\begin{array}{l}\text { Millions of prawns } \\
\text { Metric ton } \\
\text { Boat } \\
\text { Day } \\
\text { Boat-day }\end{array}$ & $\begin{array}{r}321 \\
1,970 \\
120 \\
59 \\
7,080\end{array}$ & $\begin{array}{r}313 \\
2,100 \\
120 \\
64 \\
7,680\end{array}$ \\
\hline \multicolumn{4}{|l|}{ Case Two } \\
\hline $\begin{array}{l}\text { Total expected profit (mean value) } \\
\text { Standard deviation of expected profits }\end{array}$ & AS & $\begin{array}{r}728,000,000 \\
22,000,000\end{array}$ & $\begin{array}{l}705,000,000 \\
145,000,000\end{array}$ \\
\hline \multicolumn{4}{|l|}{ Mean Values at Steady State } \\
\hline $\begin{array}{l}\text { Total stock size } \\
\text { Annual catch } \\
\text { Number of boats in a year } \\
\text { Fishing days in a year } \\
\text { Total boat days per year }\end{array}$ & $\begin{array}{l}\text { Millions of prawns } \\
\text { Metric ton } \\
\text { Boat } \\
\text { Day } \\
\text { Boat-day }\end{array}$ & $\begin{array}{r}312 \\
2,200 \\
120 \\
69 \\
8,280\end{array}$ & $\begin{array}{r}315 \\
2,100 \\
120 \\
64 \\
7,780\end{array}$ \\
\hline \multicolumn{4}{|l|}{ Average Values per Year } \\
\hline $\begin{array}{l}\text { Total stock size } \\
\text { Annual catch } \\
\text { Number of boats } \\
\text { Fishing days } \\
\text { Total boat days }\end{array}$ & $\begin{array}{l}\text { Millions of prawns } \\
\text { Metric ton } \\
\text { Boat } \\
\text { Day } \\
\text { Boat-day }\end{array}$ & $\begin{array}{r}305 \\
2,140 \\
120 \\
67 \\
8,040\end{array}$ & $\begin{array}{r}309 \\
2,060 \\
120 \\
63 \\
7,560\end{array}$ \\
\hline \multicolumn{4}{|l|}{ Case Three } \\
\hline $\begin{array}{l}\text { Total expected profit (mean value) } \\
\text { Standard deviation of expected profits }\end{array}$ & AS & $\begin{array}{r}603,000,000 \\
55,000,000\end{array}$ & $\begin{array}{l}615,000,000 \\
119,000,000\end{array}$ \\
\hline \multicolumn{4}{|l|}{ Mean Values at Steady State } \\
\hline $\begin{array}{l}\text { Total stock size } \\
\text { Annual catch } \\
\text { Number of boats in a year } \\
\text { Fishing days in a year } \\
\text { Total boat days per year }\end{array}$ & $\begin{array}{l}\text { Millions of prawns } \\
\text { Metric ton } \\
\text { Boat } \\
\text { Day } \\
\text { Boat-day }\end{array}$ & $\begin{array}{r}331 \\
2,000 \\
120 \\
58 \\
6,960\end{array}$ & $\begin{array}{r}321 \\
2,180 \\
120 \\
67 \\
8,040\end{array}$ \\
\hline \multicolumn{4}{|l|}{ Average Values per Year } \\
\hline $\begin{array}{l}\text { Total stock size } \\
\text { Annual catch } \\
\text { Number of boats } \\
\text { Fishing days } \\
\text { Total boat days }\end{array}$ & $\begin{array}{l}\text { Millions of prawns } \\
\text { Metric ton } \\
\text { Boat } \\
\text { Day } \\
\text { Boat-day }\end{array}$ & $\begin{array}{r}323 \\
1,900 \\
120 \\
56 \\
6,720\end{array}$ & $\begin{array}{r}319 \\
2,000 \\
120 \\
61 \\
7,320\end{array}$ \\
\hline
\end{tabular}


TABLE 6

Summary of Profit, Stock, Catch and Fishing Effort Impacts of TAC and TAE Controls under DifFERENT SCENARIOS

\begin{tabular}{|c|c|c|c|c|c|}
\hline \multirow[b]{2}{*}{ Scenario } & \multirow[b]{2}{*}{$\begin{array}{c}\text { Total Expected } \\
\text { Profit }(\Pi) \\
\end{array}$} & \multirow{2}{*}{$\begin{array}{l}\text { Standard } \\
\text { Deviation } \\
\text { Expected } \\
\text { Profit }(\sigma) \\
\end{array}$} & \multicolumn{3}{|c|}{ Effects of Management Options at Steady State } \\
\hline & & & $\begin{array}{c}\text { Stock } \\
\text { Size }(S)\end{array}$ & $\begin{array}{c}\text { Catch } \\
(h)\end{array}$ & $\begin{array}{l}\text { Effort } \\
(E)\end{array}$ \\
\hline $\begin{array}{ll}\text { 1. } & \text { Base case }\left(\xi_{3}=\xi_{4}=0\right) \\
\text { 2. } & \text { Estimated } \xi_{3} \text { values, } \xi_{4}=0 \\
\text { 3. } & \text { Estimated } \xi_{4} \text { value, } \xi_{3}=0 \\
\text { 4. } & \text { Estimated } \xi_{3} \text { and } \xi_{4} \text { values } \\
\text { 5. } & \text { Estimated } \xi_{3} \text { and } \xi_{4} \text { values } \\
& \text { are reversed in equations } \\
& {[16] \text { and }[17]}\end{array}$ & $\begin{array}{l}\Pi_{T A C}=\Pi_{T A E} \\
\Pi_{T A C}<\Pi_{T A E} \\
\Pi_{T A C}>\Pi_{T A E} \\
\Pi_{T A C}>\Pi_{T A E} \\
\Pi_{T A C}<\Pi_{T A E}\end{array}$ & $\begin{array}{c}\text { Not Applicable } \\
\sigma_{T A C}<\sigma_{T A E} \\
\sigma_{T A C}<\sigma_{T A E} \\
\sigma_{T A C}<\sigma_{T A E} \\
\sigma_{T A C}<\sigma_{T A E}\end{array}$ & $\begin{array}{l}S_{T A C}=S_{T A E} \\
S_{T A C}>S_{T A E} \\
S_{T A C}<S_{T A E} \\
S_{T A C}>S_{T A E} \\
S_{T A C}>S_{T A E}\end{array}$ & $\begin{array}{l}h_{T A C}=h_{T A E} \\
h_{T A C}<h_{T A E} \\
h_{T A C}>h_{T A E} \\
h_{T A C}<h_{T A E} \\
h_{T A C}<h_{T A E}\end{array}$ & $\begin{array}{l}E_{T A C}=E_{T A E} \\
E_{T A C}<E_{T A E} \\
E_{T A C}>E_{T A E} \\
E_{T A C}<E_{T A E} \\
E_{T A C}<E_{T A E}\end{array}$ \\
\hline
\end{tabular}

scenarios that are presented in Table 5. In case one, we use the estimated standard deviation in the stock recruitment relationship provided in Table 2, but set the standard deviation in the CPUE relationship equal to zero. In the second case, we set the standard deviation in the stock recruitment relationship equal to zero, but use the estimated standard deviation in the CPUE relationship from Table 2. For the third case, we assign the estimated standard deviation of the CPUE relationship in Table 2 to the stock-recruitment relationship, and assign the estimated standard deviation of the stock recruitment relationship in Table 2 to the CPUE relationship.

The optimal solutions for the three cases are provided in Table 5 without discounting. In case one, both TAC and TAE controls generate higher expected profits than with the actual uncertainty in the fishery. As we would expect, given there is no uncertainty in the CPUE relationship $\left(\xi_{4}\right.$ $=0$ ), the TAE control is preferred over the TAC control in terms of expected mean profits. In this case, the TAE control generates a higher profit of around A $\$ 1,500$ per boat per year (nominal value). However, even in this extreme scenario the TAC control still manages to generate a lower variation in expected profits and a higher stock size than a TAE control.

In case two, there is no stochasticity in the stock recruitment relationship $\left(\xi_{3}=0\right)$, but the estimated standard deviation for the CPUE relationship of 25.23 and 23.25 for brown and grooved prawns is retained. In this scenario, the TAC control provides a higher expected mean profit of about $\$ 3,800$ per boat per year (nominal value) compared to TAE control, a lower optimal stock size at the steady state and also smaller variance for expected profits than TAE control.

In case three, the stochastic levels of stock and CPUE are swapped such that the standard deviation of the stock recruitment relationship is higher than the standard deviation of the CPUE relationship $\left(\xi_{3}>\right.$ $\left.\xi_{4}\right)$. In this scenario, unlike the results reported in Table 3, the TAE control generates a higher expected mean profit compared to a TAC control. However, the standard deviation of expected profits is almost as twice as large with the TAE control and the stock size is slightly smaller. Thus it is not clear given risk-averse fishers whether a TAE would be the preferred instrument despite the fact it generates higher expected total profits.

\section{Differences between TAC and TAE Control}

A summary of the effects of TAC and TAE controls under the three uncertainty scenarios, the base case with no uncertainty, and also with the actual estimated uncertainties in the stock recruitment and CPUE relationship is provided in Table 6. Our results are consistent with the Danielsson (2002b) one-period model in that we show that if the standard variation is greater (less than) in the stock recruitment relationship relative to the CPUE relationship then the mean expected profits at the optimum 
solution are lower (higher) with TAC versus TAE controls.

We also show for the first time, that there are important differences in terms of variation in profits, stock size, catch rate, and level of fishing effort between TAC and TAE controls under uncertainty. At least for the estimated stock recruitment and CPUE relationships that exist in the NPF, we find that even when the TAE control is preferred in terms of expected profits when $\xi_{3}>\xi_{4}$, the standard deviation of expected profits is still much less with a TAC control while the stock size is higher, and both the catch rate and level of fishing effort are less. Thus, if fishers are risk averse and/or if fishery managers attach a greater value to stock sizes because of resilience to environmental shocks (Grafton, Kompas, and Lindenmayer 2005), a TAC control may still be preferred to a TAE control even if total expected profits are higher. Using the actual estimated values (case 4 in Table 6), the optimal level of fishing effort at steady state is less with a TAC control than with TAE control. This suggests there may be a preference by fishing crew, at least in aggregate, for a TAE control if higher fishing effort is positively correlated with the number of crew employed.

\section{Fisher Behavior}

Overall, the results show important differences between the two instruments with uncertainty. In the case when a TAE control generates a higher expected mean profit, it not clear that it would necessarily be preferred over a TAC control given it also has a higher variability in profits. The relative merits of TAC control are further highlighted if we consider the possibility of "effort creep" where the regulator is not able to effectively control fishing effort because of the incentives of fishers to substitute to unregulated fishing inputs. Campbell and Lindner (1990) and Anderson (1985), in fact, argue that input controls lead to rising costs precisely as a result of input substitution. For the case of the NPF in particular, an earlier study, Kompas,
Che, and Grafton (2004) shows that input substitution in the NPF has resulted in lower technical efficiency and higher than optimal levels of fishing effort. TAC controls, however, may exacerbate discarding and by-catch, although these are problems that also exist with TAE controlled fisheries (Arnason 1994).

\section{CONCLUDING REMARKS}

This paper provides the first dynamic comparison under uncertainty of instrument choice in fisheries between a total catch control and a total effort control. Using data from the Northern prawn fishery of Australia, we provide a methodology to evaluate the two instruments and compare expected profits, stock size, catch, and effort. In a 50-year planning period, various scenarios are examined to compare optimal outcomes with a total catch and total effort controlled fishery where the uncertainty is estimated from a known stock-recruitment relationship and catch and effort data.

A base case scenario with no uncertainty shows that the two instruments - total catch or total effort-give identical outcomes provided there is perfect monitoring and enforcement. Using the estimated uncertainties in the stock recruitment and catch per unit of effort relationships, we find that a total catch control, with and without discounting, is preferred in that it generates a higher total profit, lower variance of expected profits, higher stock size, and lower catch rate and levels of fishing effort compared to a total effort control. This is because there is greater variation in the estimated catch per unit of effort relationship than in the stock recruitment relationship.

Using different specifications regarding the uncertainties, three counterfactual scenarios are analyzed to compare TAE and TAC controls under uncertainty. Ignoring the incentive issues of input and output controls or differences in management costs, the scenarios show that, for the Northern Prawn Fishery, even when TAE generates a higher total expected profit an 
effort control always has a higher variance in expected profits, a smaller optimal stock size, and higher optimal catch rate and fishing effort than a TAC control. In addition to the results for the specific fishery, the paper provides a tractable method to compare management instruments in actual fisheries under uncertainty. This allows regulators to evaluate the tradeoffs between profits and other management criteria in a dynamic context, and provide guidance on the relative merits of TAC and TAE controls.

\section{References}

Anderson, L. G. 1985. "Potential Economic Benefit from Year Restrictions and License Limitation in Fisheries Regulation." Land Economics 61 (Nov.): 409-18.

Arnason, R. 1994. "On Catch Discarding in Fisheries." Marine Resource Economics 9 (3): 189-207.

Australian Bureau of Agriculture and Resources Economics (ABARE). 1994-2001. "Surveys of Northern Prawn Fishery." Unpublished statistics extracted from ABARE Fish Survey Database in the SAS System, Canberra. -1990-2003. Australian Fisheries Statistics. Canberra.

Australian Fishery Management Agency (AFMA). 1999. "The Northern Prawn Fishery Amended Management Plan, 1999." Canberra. 2002. "Northern Prawn Fishery - Strategic Assessment and Bycatch Action Plan." Draft for public comment.

- 2006a. "Northern Prawn Fishery Statistics." Unpublished database of logbook data. Canberra. . 2006b. "Northern Prawn Fishery-Strategic Plan 2001-06." Prepared by the Northern Prawn Fishery Advisory Committee.

Berman, M., and U. R. Sumaila. 2006. "Discounting, Amenity Values, and Marine Ecosystem Restoration." Marine Resource Economics 21 (2): 211-19.

Campbell, H. F., and R. K. Lindner. 1990. "The Production of Fishing Effort and the Economic Performance of Licence Limitation Programs." Land Economics 61 (Feb.): 56-66.

Campbell, H. F., A. J. Hand, and A. D. M. Smith. 1993. "A Biological Model for Management of Orange Roughy Stocks.' Marine Resource Economics 8 (2): 155-73.

Clark, C. W., and G. P. Kirkwood. 1986. "On Uncertain Renewable Resource Stocks: Opti- mal Harvest Policies and the Value of Stock Surveys." Journal of Environmental Economics and Management 13 (3): 235-42.

Crocos, P. 1987a. "Reproductive Dynamics of the Grooved Tiger Prawn, Panaeus semisulcatus, in the North-western Gulf of Carpentaria, Australia." Australian Journal of Marine and Fresh Water Research 38 (1): 79-90.

-. 1987b. "Reproductive Dynamics of the Grooved Tiger Prawn, Panaeus esculentus, and Comparison with P. semisulcatus in the NorthWestern Gulf of Carpentaria, Australia." Australian Journal of Marine and Fresh Water Research 38 (1): 91-102.

Commonwealth Scientific and Industrial Research Organisation (CSIRO). 2002a. "Northern Prawn Fishery Statistics Logbook." Unpublished database conducted by CSIRO prepared by C. M. Dichmont, D. Die, A. E. Punt, W. Venables, J. Bishop, A. Deng, and Q. Dell.

. 2002b. "Database for Northern Prawn Fishery". Unpublished CSIRO research by C. M. Dichmont, D. Die, A. E. Punt, W. Venables, J. Bishop, A. Deng, and Q. Dell.

Danielsson, A. 2002a. "Optimal Catch Quotas and Effort Quotas in the Presence of Risk." Paper presented at the International Conference of the International Institute of Fisheries Economics and Trade, New Zealand, 2002. 2002b. "Efficiency of Catch and Effort Quotas in the Presence of Risk." Journal of Environmental Economics and Management 43 (1): 20-33.

Galeano, D., S. Vieira, W. Sharon, and P. Newton. 2006. "Australian Fisheries Surveys Report 2005." ABARE report prepared for the Fisheries Resources Research Fund, Canberra. Available at http://www.abareconomics. com/publications_html/fisheries/fisheries_06/ AusFishSurvey_05.pdf.

Goldberg, D. E. 1989. Genetic Algorithms in Search, Optimization and Machine Learning. Boston: Addison-Wesley.

Grafton, R. Q., T. Kompas, and D. Lindenmayer. 2005. "Marine Reserves with Ecological Uncertainty." Bulletin of Mathematical Biology 67 (5): 957-71.

Grafton, R. Q., R. Arnason, T. Bjørndal, D. Campbell, H. F. Campbell, C. W. Clark, R. Connor, D. P. Dupont, R. Hannesson, R. Hilborn, J. E. Kirkley, T. Kompas, D. E. Lane, G. R. Munro, S. Pascoe, D. Squires, S. I. Steinshamn, B. R. Turris, and Q. Weninger. 2006. "Incentive-based Approaches to Sustainable Fisheries." Canadian Journal of Fisheries and Aquatic Sciences 63 (3): 699-710. 
Hannesson, R., and S. I. Steinshamn. 1991. "How to Set Catch Quotas: Constant Effort or Constant Catch." Journal of Environmental Economics and Management 20 (1): 71-91.

Kompas, T., and T. N. Che. 2003. "Management Options under Uncertainty: A Bioeconomic Model of the Australian Northern Prawn Fishery." ABARE Report to Fisheries Resources Research Fund. Canberra: Australian Bureau of Agricultural and Resources Economics.

Kompas, T., T. N. Che, and R. Q. Grafton. 2004. "Technical Efficiency Effects of Input Controls: Evidence from Australia's Banana Prawn Fishery." Applied Economics 36 (15): 1631-41.

Penn, J., W. Caputi, and N. G. Hall. 1995. "Spawner-Recruit Relationships for Tiger Prawn (Panaseus esculentuc) Stocks in Western Australia." ICES Marine Science Symposia (Acts du symposium) 199:320-33.

Quiggin, J. 1992. "How to Set Catch Quotas: A Note on the Superiority of Constant Effort Rules." Journal of Environmental Economics and Management 22 (2): 199-203.
Reed, W. J. 1979. "Optimal Escapement Levels in Stochastic and Deterministic Harvesting Models." Journal of Environmental Economics and Management 6 (4): 350-63.

Ricker, W. E. 1954. "Stock and Recruitment." Journal of the Fisheries Research Board of Canada 11:559-623.

Sumaila, U. R., and C. Walters. 2005. "Intergeneration Discounting: A New Intuitive Approach." Ecological Economics 52 (2): 13542.

Townsend, R. E. 1990. "Entry Restrictions in the Fishery: A Survey of the Evidence." Land Economics 66 (Nov.): 359-78.

Wang, Y. G. 1999. "A Maximum-Likelihood Method for Estimating Natural Mortality and Catchability Coefficient from Catch and Effort Data." Marine Freshwater Research 50 (4): $307-11$.

Wang, Y. G., and D. Die. 1996. "Stock-Recruitment Relationship of the Tiger Prawns (penaeus esculentus and penaeus semisulcatus) in the Australian Northern Prawn Fishery." Marine and Freshwater Research 47 (1): 87-95. 